\title{
THE IMAGE OF NEW WOMEN IN SHOBHA DE'S NOVEL SOCIALITE EVENINGS
}

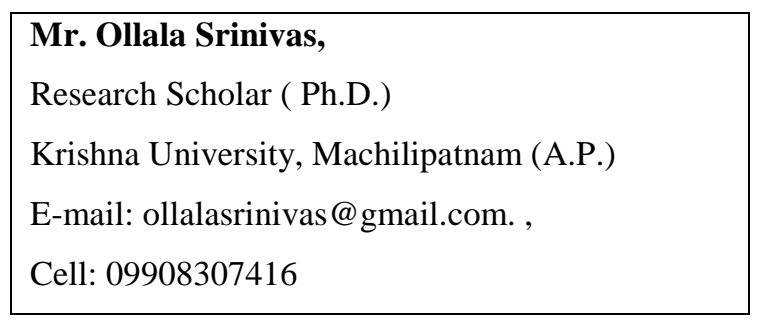

\begin{abstract}
Shobha Rajadhyaksha is a well known novelist by the name of Shobha De in the realm of Indian English novel. Shobha is a gifted novelist with extraordinary ability to discuss very sensitive aspects of human life tactfully. The way she narrates each and every aspect of human relationship in general and man-woman relationship in particular, is superb. Shobha differs from other Indian women novelists writing in English. She is a writer who believes in very frank narration of incidents and absolute open-heartedness.

The present paper is a study of Shobha De's first novel Socialite Evenings. De conceives the extramarital affairs of women as the stroke to break the traditional and moral values in society. Socialite Evenings is about the journey of a prominent Bombay socialite Karuna, from a middle class girl to a self-sufficient woman. Making a feminist approach, the novel gives us the picture of the marginalization of the Indian women at the hands of their husbands. Socialite Evenings is a novel that presents the institutions of family and marriage existing in the wealthy class of the Indian society. This portrayal is authentic, being an inside story, because the narrator herself belongs to this class. Socialite Evenings is a romantic tale, suffused with feminist traits. An enduring theme in the novel is the image of new women, search for identity and selfhood.
\end{abstract}

Keywords: Feminism, Struggle for identity, Sex ,marriage, Image of new women.

Indian fiction in English has been enriched by several talented women novelists including Kamala Markandaya, Anita Desai, Nayanatara Sahyagal, Attain Hosain, Santharamarau, Shashi Deshpande and Shobha De. They have a women perspective on the world. They have written about Indian women, their struggle, their suffering and their awkward position, keeping in view their image and role which the society has created. Their chief contribution consists of their exploring the moral strength of women characters and their struggle with challenges in creating their own identity.

Shobha De is a prolific writer born in Maharashtrian Brahmin Family in Mumbai in 1948 and was educated in Delhi and Bombay. She graduated from St.Xavier's College, Bombay with a degree in Psychology. She has achieved top most position in the queue of best-selling writers in India. All the twelve books which were written by her gained high score in the charts as well as created new records. She writes about the high-flying- 
upperclass society of India. She has dealt with issues related to woman.To project urban culture, she has changed tradition picture of enduring, submissive and selfsacrificing women with a new picture of bold and liberated urban women. Shobha De is renowned for bold and frank style of writing. She explored the lives of bored housewives and their loveless rich husband and family. Her novels mirror the life styles of the elite and the middle classes of urban world.

Socialite Evenings is Shobha De's first novel published in 1988. The novel portrays Mumbai high society and explores the lives of bored rich housewives trapped in loveless marriages and engaging in ill-fated, extra-marital affairs, smug selfish husbands, fashionable parties, false spiritual leaders, and a portrait of general moral, spiritual and intellectual bankruptcy and decadence of the elite who have traded their traditional culture for westernisation and modernisation. In the novel, Karuna the main protogonist and narrator caught up in a drab, boring life that she seeks to escape by writing memoirs. Her memoirs are successful and she achieves a mesure of fame and pride in herself as she becomes an active socialite and eventually uses her new found prominence as celebrity to get herself a position as an advertising copy writer and creator of a telivision series.

In the novel Socialite Evenings ${ }^{1}$ Karuna is the main protogonist. She is all agog to break-out of such thralldom which compels her to assume the status of the other. A problem child both at home and at school, she declines a dog the traditional path of etiquette and manners. At home, she refused to cower before elders and at school she wore her sash hipster style. As she grows in age there develops in her the emotional urge to identity with the outside world, the modern crowd, the bewitching and fascinating world of affluent girls who had the lewd and clandestine world of modeling with her secret assignment as the Terkosa Girl. Throughout the novel Karuna figures as a woman who asserts her feminine psyche through protest and defiance. She figures as a woman, not victim. Shobha De deals with the sullenly skewed of art. We do not have here the stereotypes associated with male artistic representations of women. Karuna's initiation into the fashionable world of modern life begins at Anjali's fancy place in Malabar Hill. But Anjali accuses Karuna of bitchiness and lechery, her insatiable appetite for sex. This is borne 
ELK

Asia Pacific Journals

out when Karuna dates with the New Delhi ad film-maker in London. Further her stay in the United States gives her a feeling of superiority and makes her assertive. Karuna, with all her attempts at egoassertion, refuses subscription to stereotypes, to succumb to the hegemony of the malist culture.

\section{Socialite Evenings gives us the} image of new women at the hands of their husbands. Shobha De's is the picture of women not only as protagonists but also as motivating factors in society, initiating and regulating their own lives as well as the lives of others in the voluptuously fascinating world of Bombayites, its enticing glitter and glamour enamoring many a Karuna to its ensnaring and captivating gossamer. Karuna's marriage is a failure since it is loveless, joyless and bridgeless. There is no understanding between the husband and wife. She feels that she has married "the wrong man for the wrong reasons at the wrong time. Her husband is just the average Indian husband, Unexciting, uninspiring, untutored. He was not made for introspection. The average Indian woman's conjugal life is to her an exhausted generation of wives with no dreams left and marriage is like a skin
ELK Asia Pacific Journals - Special Issue ISBN: 978-81-930411-1-6

allergy, an irritant.But she is not afraid to face this irritant, this allergy. She boldly and defiantly encounters it, for she realizes "marriage is nothing to get excited or worried about. It is just something to get used to" (68) and she gets used to this stereotyped social institution in the course of time. She detests the stand-offish and callous attitude of the husbands who often kept themselves busy in drab monotonous activities - like reading and business pages of The Times of India. But despite these laxities, a husband was above all, a sheltering tree, a rock to the wife. They were not wholly bad or evil and the wife as a woman was only peripheral being, Karuna says:

We were reduced to being
marginal people. Everything that mattered to us was trivialized. .........roof over our head and four square meals a day. (69)

The subordination of women as housewives stems from a castration-panic on the part of the husband. The Indian male is presented by Shobha De as a person "terribly threatened by selfsufficient women." (69) He is inadequate and incomplete as a husband since he lacks 


\section{Asia Pacific Journals}

the traits of an ideal husband. Fear of the loss of domination and control over the self-affirming wife makes him resort to several defence mechanisms. One of these strategies is his male chauvinism and power-assertion ventilating in bullying and committing atrocities upon his wife. But his stupid self-conceit and ego restricts a free exchange of views among sexes. Karuna inquisitively wonders: "how could he communicate anything at all to men who perpetually sat reading pages of The Times of India while concentratedly picking their noses?" (69)

Karuna learns from Ritu, whom she chances upon at a finance director's party that "men like dogs could be conditioned through reward and punishment." (87) But could she condition her husband in the like manner. But she was fed up with her husband's compulsive socializing, his horrible safari suits and the gum he constantly chewed. She could not turn to anything in such a boring milieu save her books and her fantasies. Crosswords and newspaper chess were other alternatives to utter boredom. She realizes that despite her little acts of protest, she is "a well-trained Indian wife" (54) but she shares the same rational human nature as men do. Karuna is not "the toy of man, his rattle," which "must jingle in his ears whenever, dismissing reason, he chooses to be amused."

The subordination of women in the malist culture is symptomatic of hierarchization of socio-moral values between the sexes. It symbolizes the polarity between activity and passivity, between meek obedience and defiance. Helene Cixous observes: "A male privilege can be seen in the opposition between activity and passivity. Traditionally, the question of sexual difference is coupled with the same opposition: activity/passivity."10 Women are often the symbols of passivity.Helene Cixous further maintains: "Either the woman is passive; or she doesn't exist. What is left is unthinkable, unthought of. She does not enter into the opposition, she is not coupled with the father who is coupled with the son." (288)

Woman is thus reduced to matter, a mere object. This reduction of woman to matter or a commodity is in the main a phallocentric pattern. Karuna's husband treats her as matter, a mere object subjected to his own will. Karuna's humorously sarcastic approach to her problems in the patriarchal male culture apparently deconstructs the traditional 
gender hostility used to elaborate the polarities of connubial ties. Karuna undermines male superiority. She loathes her husband's dwelling in "post-mortems." (186) She makes an ingenuous declaration about her inner urge to express herself through love:

"I love this friend of yours, and I want to be with him in Venice. There is a good chance ............It's the Taurean in me that's surfacing these days. Treat this as a short-term mania that will wear itself out." (186)

It is clear that Karuna has just a formal relationship with her husband. Intimacy between the husband and wife is lacking for Karuna who never calls her husband by his name but derogatorily as 'Black Label.' Shobha De resorts to the technique of manipulating language in order to deconstruct the male ego: "the fact that his wife had taken a lover excited him. resisting - it would have only consumed more time." (188)

Women in Shobha De's novels symbolize the overpowering materialism and the lack of spirituality that characterizes modern age. With the crumbling of moral and ethical values there is an inner conflict which drives the modern Indian women to seek shelter in different identities for momentary solace. One of the most notable features of these women is they lack an identity. But the whole blame cannot be laid on women only because in Shobha De's novels there are type of men who use and abuse women and then discard them. In Socialite Evenings one encounters a liberal Indian husband who allows his Indian wife to go abroad and get herself screwed once for all as the last gesture of good will. From the individual, it comes to the family. It is the family which is the centre of deviance. Subhash Chandra regards family's disintegration is the instrument of degeneration of Socialite Evenings.

Anjali throws off the traditional conventions of moral values and seductively rises to the social status of the upper classes. She enacts a marriage of choice with Abe, an experienced rake with a wild reputation and rejoices in orgastic acrobatics. Having a passion for illimitable sex, she has frequent sex encounters. Be he the die-hard rake Abe or the innocent Karan, she is after the desire of the body, the itchings of the sensations. Karuna too 
discards the dogmatic rules of a hackneyed and worn-out tradition for sustaining and cherishing her extra-marital relationship with Krish. Even she does not hesitate to restrain her husband from a week-long sexual orgy with Krish in Rome. Anjali, Karuna and Ritu are the proverbial succubi who reign supreme in their world of licentious and unrestricted libido. In Socialite Evenings, Shobha De articulates her own inclination towards vamp art and displays the troika of female characters who symbolize absolute freedom of womankind from all forms of patriarchal inhibitions.

Karuna rejects the hierarchization of male values where the female factor is reduced to a negative, and almost nullified. Her statements express her desire for the affirmation of her feminine consciousness. It is in fact a search on her part for the genuine female self in a male-centered world. But hers is not a traditional one. It is an esoteric quest, something weird and grotesque on the part of an Indian woman. But Karuna never bothers about the social repercussions her esoteric quest might entail. She is isolated from the traditional Indian heritage and its social implications. Taking up a nonconformist stance, she adopts a radical feminist point of view all agog to destroy the sex/gender system - the real source of women's oppression - and to create a new society in which men and women are equals at every level of existence. With dissident women like Karuna and Anjali oppressive gender roles will be deconstructed and women will take up a revolutionary role, flouting androgyny. A new generation of wild, lusty, and wandering women like those of De's female protagonists will be created who would prefer to identify themselves as radical lesbian feminist separatists. Pornography in the novel becomes the symbol and symptom of the female defiance of a male-regulated female sexuality. Her women suffer in an androgynous world fro they do not cherish genuine passions but only plastic passions which make them passive without a sense of purpose living in a frustrating world of anxiety, guilt, hostility, bitterness, boredom and resentment. These women cast off the conventional sense of morality, the old, tired and repressive sexual moves and revel in the erotic celebration of the body.

Thus Shobha De's novel Socialite Evenings shows the image of new woman against predatory male-dominated society. 


\section{ELK}

Asia Pacific Journals

But her vamp ideology of feminism provides no redemption for the deviant and fallen women who in their frantic struggle to escape male-domination and attain individuality, meet with failure and are victimized in one way or the other. In enacting the drama of seduction and betrayal in her foray against patriarchal structures, the glamorous vamp in De's novels, may end up being as seductively treacherous to women as to men. A woman in Indian society marries not just the man but also his family and subsequently loses her identity in marriage, relinquishes her freedom and sets about pleasing everybody. But the new generation of women with their new-found release from matrimonial bondage adopts different perspectives, and revolt against the old order. De's women are such liberated individuals in search of a niche in their lives.

\section{NOTES}

[1] Shobha De, Socialite Evenings, (New Delhi: Penguin, 1989).

[2] R.Selden, ed., The Theory of Criticism: From Plato to the Present: A Reader (London: Longman, 1988), 534.
ELK Asia Pacific Journals - Special Issue ISBN: 978-81-930411-1-6

[3] Subhash Chandra, "Family and Marriage in Shobha De's Socialite Evenings,"

[4] Simone de Beauvoir, The Second Sex, trans. And ed. H.M.Parshley (London:

a. Penguin, 1974), 85.

[5] K.R.Srinivasa Iyengar, Indian Writing in English (New Delhi: Sterling, 1983) 92.

[6] C.P.Surendran, "Just Another De," The Illustrated Weekly of India: 6 Nov.1992, 12. 